\title{
Google AdSense Publisher Taxation Obligation
}

\author{
Mirza Ramadhan ${ }^{1 *}$, F.C. Susila Adiyanta ${ }^{1}$, Nabitatus Sa'adah ${ }^{1}$ \\ \{Mirza.Ramadhan999@gmail.com ${ }^{* 1}$, susilaadiyanta@live.undip.ac.id², nabitatass@ gmail.com³
}

Fakultas Hukum, Universitas Diponegoro, Jl. Prof. H. Soedarto, S.H., Semarang, Indonesia $50275^{1}$

\begin{abstract}
People always strive to fulfill all the needs of materiel. Nowadays, the needs of these materials can be obtained with money and one way of earning money is by doing business. With the development of technology, a business can be done with the help of Internet technology. AdSense is an Internet advertising program that provides an opportunity for website owners or bloggers to earn money by showing AdSense ads on their websites in the hopes of being clicked by website visitors. This research is aimed to know what tax obligations are imposed on websites or bloggers who are professional advertising publishers of Google AdSense. This research uses qualitative methods with a descriptive approach. The results of this study show that Google AdSense advertising publishers are subject to tax income $\mathrm{PPh}$ article 23 sourcing from Google AdSense, which is a tax object that can increase state acceptance.
\end{abstract}

Keywords: Tax Duty, Publisher Google AdSense, Blogger.

\section{Introduction}

Technological developments continue to be discovered in order to facilitate human life, especially in the field of communication. Discovery after discovery was born until the discovery of the internet in the 1960s [1]. The internet is a long-distance system of various computer networks connected by modems or telephone lines [2]. The emergence of the internet has had a major impact on society. The internet has entered into various segments of human activity, whether in the political, social, cultural, and economic and business sectors. For example, the internet is used to communicate, search for actual news, find information, buy and sell transactions, even to conduct payment transaction [3].

Along with the times and increasing human population, the internet, which was originally used for communication needs only, developed into a source of income, both as a source of side income and a primary source of income. There are various ways to get income through the internet, one of which is through online advertising business. One such online advertising business is Google AdSense. Google AdSense is an online advertising program from Google, which is one of the sources of income from the internet today, people who pursue Google AdSense business are called Google AdSense advertisers.[4] An ad publisher is someone who provides space on his website as a place to advertise a product[5].

One example of Indonesian people who managed to earn income by becoming a Google AdSense ad publisher is Eka Lesmana. The success of Eka Lesmana in earning his income from Google AdSense was published in the Central Java Tribune. The news mentioned that Google AdSense income of Eka Lesmana could reach IDR. 120 million (one hundred twenty million rupiah) per month. Eka Lesmana or known as Eko Purwanto is a duck farmer from Karanganyar who earns millions of rupiah per month from Google AdSense.[6], [7] Based on 
the news, of course, a Google AdSense ad publisher can potentially be subject to income tax $(\mathrm{PPh})$, but in capturing the potential tax will be difficult to implement because there are no clear rules governing tax collection for someone who earns income from the internet, especially those who pursue business as a Google AdSense ad publisher.

It is unfortunate if the tax potential like this is not maximally utilized by the tax authorities. Seeing the number of internet users in Indonesia hitting 143 million and will continue to rise every year [8], impacting the growth in earnings of Google AdSense ad publishers.

Based on the description above, the identification and formulation of the main issues are as follows:

1. Is the Google AdSense publisher, including the subject of income tax, and the income of the Google AdSense publisher subjected the income tax object?

2. What are the tax obligations of individual taxpayers who work as Google AdSense ad publishers?

\section{Method}

This research uses an empirical juridical approach. The method of analyzing the results of this study uses descriptive analytical methods. Scientific activities include verification, comparison with various sources and research informants related to the research topic.

\section{Results and Discussion}

\subsection{Characteristics of Google AdSense Ad Publishers}

\subsubsection{Potential of the Internet as a Source of Income}

The development of technology, especially information technology which is so rapid causing globalization. Understanding globalization according to Manfred B. Steger is:

"Globalization is essentially a process of social transformation that will bring the different and scattered conditions of humanity in many regions of the world to a single condition that knows no boundaries."[9]

The emergence of computer technology as a data processing tool which is then followed by the emergence of internet technology that is present as a means to facilitate the work of humans to communicate. The internet can be interpreted as a broad and worldwide computer network that connects computer users from one country to another in the world where there are various information resources ranging from static to dynamic and interactive[10], [11]. The internet was originally used for military purposes, in 1969 through the Advanced Research Projects Agency (ARPA). ARPA is the United States defense agency responsible for developing technology for military purposes has developed a computer network system that is spread by connecting computers in vital areas for military communication purposes[12].

Over time and the development of science and technology, the existence of the internet is not only used in the military field, but also used for other fields. One of which is in the field of commerce (e-commerce).[13] According to Nurfansa, e-commerce is an abbreviation of 
electronic commerce which can be defined as a mechanism of buying and selling transactions using internet facilities as a communication medium [14].

The Directorate General of Taxes has a simpler classification of e-commerce activities. According to the Directorate General of Taxes in SE-62/PJ/2013, it divides all e-commerce transactions into four models. This classification is made to facilitate the perpetrators of ecommerce. The following is a further explanation of the classification [14]:

Table 1. Further explanation regarding the classification of e-commerce models

\begin{tabular}{|c|c|}
\hline Ecommerce model & Information \\
\hline Online Marketplace & $\begin{array}{l}\text { Provides a place of business activities in the form of an Internet Shop at } \\
\text { an Internet Mall as an online Marketplace Merchant selling goods or } \\
\text { services. Related parties are the organizer, merchant and buyer } \\
\text { Example: tokopedia.com, rakuten.com, bukalapak.com, duniavirtual.com }\end{array}$ \\
\hline Classified Ads & $\begin{array}{l}\text { Provides a place and/or time to display goods and/or service content for } \\
\text { Advertisers to advertise their products or services through a site provided } \\
\text { by Classified Ads Providers. Related parties are organizers, advertisers } \\
\text { and ad users. } \\
\text { Example: Olx.com, kaskus.com, ebay.com }\end{array}$ \\
\hline Daily Deals & $\begin{array}{l}\text { Provides a place of business activities in the form of a Daily Deals } \\
\text { website as a Daily Deals Merchant site selling goods or services to buyers } \\
\text { using vouchers as a means of payment. Related parties are the organizer, } \\
\text { merchant and buyer. } \\
\text { Example: dealgoing.com }\end{array}$ \\
\hline Online Retail & $\begin{array}{l}\text { The activity of selling goods and or services carried out by Online Retail } \\
\text { organizers to buyers on the Online Retail site. The parties involved are the } \\
\text { organizers who also act as merchants and the other parties are buyers. } \\
\text { Contoh: bhinneka.com, gramedia.com }\end{array}$ \\
\hline
\end{tabular}

E-commerce in various forms, has promising business opportunities in Indonesia. Indonesia as a developing country with a population of 264.16 million is ranked 6th in the world as the country with the most internet users in the world after Japan and Brazil[15]. Internet users in Indonesia have experienced rapid growth in the last 5 years [8]. There were around 82 million users in 2013, and the number was doubled in 2017 with 143 million users.

Statistical information about internet users in Indonesia which is ranked 6th in the world shows that the internet has the potential to be used as a source of income.

\subsubsection{Google AdSense as a way to get income through the internet}

Google AdSense is one of the services made by Google to website owners/bloggers to be able to make money by displaying AdSense ads on Blogger's sites. Blogger is a designation for content creators in the form of writing, images, or videos which are then displayed on his website, the content will later be displayed on the website so that it can be consumed and useful for citizens, for example: websites that contain content about cooking guides, designs home, movie streaming, song downloads and so on [16]. Bloggers who display AdSense ads are called Google AdSense ad publishers. Google AdSense ad publishers will get a commission based on clicks made by site visitors on AdSense ads that appear on the site of the publisher's ads without any sales having to occur on these ads. this remuneration system is known as a pay per click (PPC) or pay per click system. PPC (pay per click) is a type of online advertising program that provides commissions based on the number of clicks that get on the 
ads displayed on the site without any sales having to occur on these ads, and what is needed to get commissions is only through ad clicks [17].

Google chooses a Blogger which has a website with quality content in it to be a Google AdSense ad publisher. The good quality of content will make visitors satisfied to consume the content and the popularity of the website will rise[18].

\section{(a) How Google AdSense works}

Google AdWords is Google's advertising installation service intended for advertisers who want to advertise their products on Google by displaying advertisements from advertisers on websites owned by Google AdSense ad publishers or in Google search results. Any advertisement will reach the desired website visitors/citizens, and citizens will know what products and services are displayed on the ad. Instead, advertisers must pay promotional costs to Google[17].

There is a kind of cooperation between Google AdWords and Google AdSense. Google AdWords acts to serve advertisers who want to advertise their products on Google, and Google AdSense has a role to serve website owners who want to earn money by displaying ads that come from Google AdWords. In other words, Google acts as an agent that connects advertisers who want to advertise their products through website media, and website owners who want to earn money from displaying advertisements.

Advertisers who want to advertise their products on Google pay promotional costs and send advertising material through Google AdWords services. Google AdSense is in charge of displaying ads from Google AdWords through Google AdSense ad publishers' websites. In other words, AdSense ads that appear on Google AdSense ad publisher websites come from Google AdWords. Google AdSense ad publishers are paid by Google in the form of commissions derived from promotional costs paid by advertisers through Google AdWords, the amount of commission earned depends on the number of visitors click on AdSense ads on the website of the ad publisher [18].

Advertisers will benefit because their products can be seen and known by audiences, especially internet users because they appear on the website of Google AdSense ad publishers so that the product has the potential to sell better in the market. Ad agencies (in this case Google) get benefits from advertisers every time they want ads to be displayed on the internet. At the same time, Google AdSense ad publishers also get commission from Google AdSense for displaying the ads which potentially are clicked by visitors[17]. 


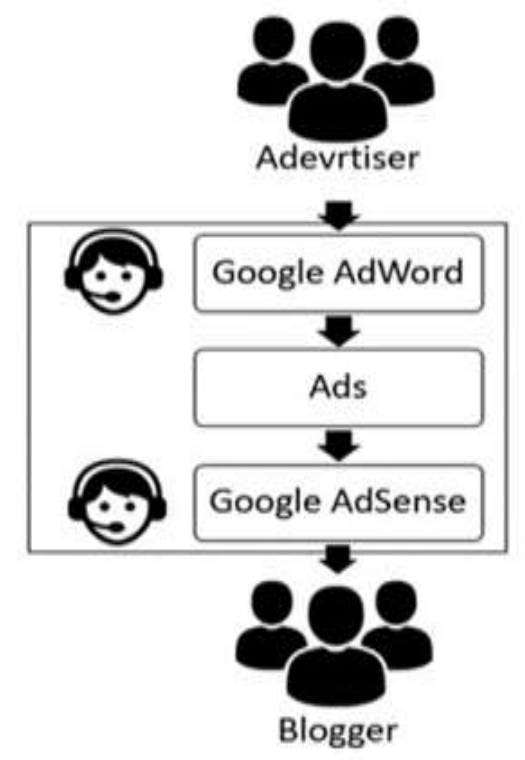

Source: Earnings with Google AdSense [18].

Figure 1. Schematic of how Google AdSense works

\subsubsection{Criteria for Establishing Subjects and Income Tax Objects for Google AdSense Ad Publishers}

Tax is a compulsory levy paid by the people to the state and used for public purposes[19]. The state makes tax as the main source of state finance to carry out infrastructure development and finance the running of the government [20].

One type of tax that plays an important role in increasing state revenue is Income Tax $(\mathrm{PPh})$, which is regulated in Law Number 36 of 2008 [21]. An income tax is a tax that is imposed on individuals and individuals and entities relating to income received or obtained for one year tax [20].

Generally in Article 2 paragraph (1) of the Income Tax Law, the understanding of the subject of taxation is who is subject to income tax. The tax subjects in the article include individuals, inheritance which has not been divided as one unit replacing the entitled, the body, and a permanent establishment (BUT). Article 2 paragraph (2) of the Income Tax Law still distinguishes the four income tax subjects into two types, namely domestic tax subject and foreign tax subject [19].

Domestic personal tax subject becomes a Taxpayer if he has received or received income that exceeds the Taxable Income. The subject of domestic corporate tax has been the taxpayer since its establishment, or domiciled in Indonesia. While foreign tax subjects, both individuals and entities, can become taxpayers if they receive and/or obtain income from Indonesia or receive and/or obtain income from Indonesia through permanent establishment in Indonesia [22].

Article 4 paragraph (1) of Law Number 36 of 2008 explicitly states that income is any additional income obtained by the taxpayer both from domestic and abroad, which can be used to increase the wealth of the taxpayer concerned, by name and in any form. 


\section{(a) Various income taxes in the Income Tax Law}

a. Article 21 Income Tax

$\mathrm{PPh} 21$ is a withholding tax that is imposed on income received by a Domestic Personal Taxpayer (WPOP) for work, services, or activities that it does. Broadly speaking, income withheld by Article 21 Income Tax is divided into two categories, namely the Income Tax 21 Object (which is further divided into "subject to final income tax" and "not subject to final income tax") and is not subject to Income Tax 21. Detailed by the provisions of the Minister of Finance Number 252/PMK.011/2012 and in Article 5 of the Director General of Taxes Regulation No. Per-16/PJ/2016 are as follows [23]:

Table 2. Details of Objects withholding Article 21 Income Tax

\begin{tabular}{|c|c|}
\hline Income Tax 21 & Form/Example \\
\hline $\begin{array}{l}\text { Income received or obtained by permanent } \\
\text { employees. }\end{array}$ & Regular or irregular income \\
\hline $\begin{array}{l}\text { Income received or obtained regularly by pension } \\
\text { recipients. }\end{array}$ & Pension or similar income. \\
\hline $\begin{array}{l}\text { Income related to termination of employment and } \\
\text { income related to pensions received } \\
\text { simultaneously. }\end{array}$ & $\begin{array}{l}\text { Severance pay, } \\
\text { Pension benefits, } \\
\text { Old-age benefits or old age benefits, and } \\
\text { Other payments of the same type. }\end{array}$ \\
\hline $\begin{array}{l}\text { Earnings of temporary employees or casual } \\
\text { workers. }\end{array}$ & $\begin{array}{l}\text { Daily wages. } \\
\text { Weekly wages, } \\
\text { Unit Wages, } \\
\text { Wholesale wages, or } \\
\text { Wages paid monthly. }\end{array}$ \\
\hline Rewards for non-employees. & $\begin{array}{l}\text { Honorarium, } \\
\text { Commission, } \\
\text { Fee, and } \\
\text { Rewards in connection with work, services and } \\
\text { activities carried out. }\end{array}$ \\
\hline Rewards for an event & $\begin{array}{l}\text { Pocket money, } \\
\text { Money representation, } \\
\text { Money meeting, } \\
\text { Honorarium, } \\
\text { Gifts or awards with names and in any form, } \\
\text { and } \\
\text { Rewards of any name. }\end{array}$ \\
\hline 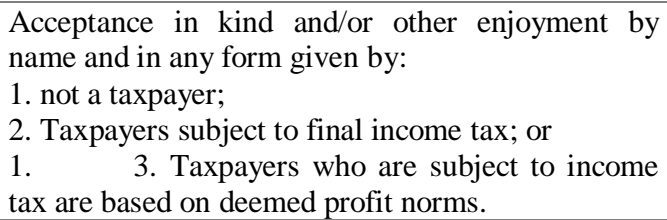 & $\begin{array}{l}\text { Income in the form of revenue in kind and/or } \\
\text { other enjoyment is based on the market price of } \\
\text { the goods given or the fair value of the benefits } \\
\text { provided }\end{array}$ \\
\hline
\end{tabular}

b. Income Tax Article 22

Income tax article 22 according to Law of income tax number 36 of 2008 is:

"The form of withholding or collecting tax carried out by one party to taxpayers and related to the activity of trading goods. This income tax is levied on certain business 
entities, both government and private, which carry out export, import and re-import trading activities."

In general, Article 22 Income Tax is imposed on export, import and re-import trade which is considered "profitable". Profitable here means that both the seller and the buyer can both take advantage of the trade transaction [23].

\section{c. Income Tax Article 23}

Article 23 Income tax $(\mathrm{PPh})$ is a tax withheld for income derived from capital, the delivery of services, gifts or awards, and income related to service fees other than those with income tax Article 21[23].

Article 23 Income Tax is one type of tax collected with a system of withholding tax (withholding or collecting). This means that the Article 23 tax collector or tax collector is a party who has been appointed by the Income Tax Law and also the implementing regulations for carrying out the deduction. These parties are government bodies, domestic corporate tax subjects, organizing activities, Permanent Establishment (PE) [22].

As the party receiving income that has been withheld Article 23 Income Tax, then the party receiving income is entitled to obtain proof of withholding from the income tax article 23. The party receiving income withheld Article 23 includes taxpayers (WP) living in the country, such as personal, entity, and Permanent Establishment (BUT) [22].

\section{d. Income Tax Article 25}

Article 25 Income Tax (PPh Article 25) is a tax paid in installments. The aim is to ease the burden of taxpayers, bearing in mind that the tax owed must be paid within one year. This payment must be made alone and cannot be represented.

\section{d. Income Tax Article 26}

Article 26 Income Tax is income tax that is imposed on income received by foreign taxpayers from Indonesia other than permanent establishment (BUT) in Indonesia.

f. Income Tax Article 4 paragraph (2)

Income Tax Article 4 Paragraph 2/Final Income Tax is income tax on certain types of income which is final and cannot be credited with the income tax payable. The final term here means that the tax deduction is only once in a tax period with consideration of convenience, simplicity, certainty, timely tax imposition and other considerations [24].

Google AdSense ad publishers who are legal subjects as citizens, have a state obligation to contribute to the country's ongoing implementation and development of the country by paying income tax. Google AdSense ad publishers must carry out their obligations as citizens by paying income tax $(\mathrm{PPh})$ on each income earned from their work as a Google AdSense ad publisher. Google AdSense ad publishers will be subject to income tax if they meet the criteria as subject and object of income tax.

The author has taken the example of Google AdSense ad publishers as follows:

1. Eka Lesmana, an Indonesian Google AdSense ad publisher who lives in Karanganyar, has been a Google AdSense ad publisher since 2013. Eka Lesmana is currently married and has one child but does not yet have a TIN. Based on interviews by the author, Eka Lesmana earned income from Google AdSense as much as Rp. 
155 million in 2018. From his income as a Google AdSense ad publisher, Eka Lesmana was able to buy a car, a plot of land and renovate his house [25].

2. Timon Adiyoso, an Indonesian Google AdSense ad publisher who lives in Samarinda City, East Kalimantan, works as HRD and Supervisor at PT Surya Teknik Anugrah Site. in addition to his job, he is also Google AdSense ad publisher since 2013. Timon Adiyoso currently married and has two children and has a TIN. Based on interviews by the author, Timon Adiyoso has a website that has a Google AdSense ad called https://www.mastimon.com/. The website contains articles that discuss Automotive, Health, Science, and so on. Timon Adiyoso promotes his website through Facebook, from the promotion https://www.mastimon.com/ can get around 4,569 visitors every day, 137,070 visitors every month, and 1,667,685 visitors every year. Website visitors https://www.mastimon.com/ come from Google search engines and social media such as Facebook and YouTube. Rrom the number of visitors, the Google AdSense revenue that Timon Adiyoso obtained was as much as Rp. 149 million in 2018. From his income as a Google AdSense ad publisher, Timon Adiyoso was able to buy a car and renovate his house [26].

3. Soim Ramadhan, a Google AdSense ad publisher and online trader, Indonesian citizen who lives in Kartasura. He has been a Google AdSense ad publisher since 2017 and is now married and has two children. Based on interviews by the author, Soim Ramadhan earned 110 million from Google AdSense in 2018 and already has a TIN. From his income as a Google AdSense ad publisher, Soim Ramadhan was able to buy a car, buy a house in Kartasura [27].

\section{(b) Google AdSense ad publishers as Income Tax Subjects}

Understanding Tax Subjects in Article 2 paragraph (1) of Law Number 36 of 2008 concerning Income Tax includes individuals, inheritance, entities and permanent establishments. Individuals as Tax Subjects may reside or lives in Indonesia or outside Indonesia. From the two data obtained by the author, Eka Lesmana and Soim Ramadhan are subject to personal taxation, this can be seen from their residency.

Understanding Tax Subjects in Article 2 paragraph (1) of Law Number 36 of 2008 concerning Income Tax includes individuals, inheritance, entities and permanent establishments. Individuals as Tax Subjects may reside or be in Indonesia or outside Indonesia. Based on the tax subject provisions, Eka Lesmana, Soim Ramadhan, and Timon Adiyoso are included in the domestic income tax subject.

Eka Lesmana, Timon Adiyoso, and Soim Ramadhan can be categorized as free workers, since they work as blogger and work on their own behalf. Eka Lesmana, Timon Adiyoso, and Soim Ramadhan create article content without anyone's command and the three of them are responsible and hold full rights to all websites that they have and their contents.

In terms of its role as a Google AdSense ad publisher. The Google teamed up with Eka Lesmana, Timon Adiyoso, and Soim Ramadhan to display AdSense ads on the websites of the three people. Google wants to collaborate with Eka Lesmana, Timon Adiyoso, and Soim Ramadhan because of the competence of the three of them as professional bloggers who are able to lead many visitors to their websites, with the number of visitors generated, the potential for visitors to click AdSense ads is greater so that AdSense income Eka Lesmana, Timon Adiyoso, and Soim Ramadhan also gained more and more.

In addition, Google as an advertising agency, and advertisers who advertise their products on Google also benefit, advertisers benefit because their products can be known and known by people because they appear on the website of Eka Lesmana, Timon Adiyoso, and Soim 
Ramadhan so that advertisers' products have the potential to sell better in the market. Google as an ad agency also benefits from being paid by advertisers every time an advertisement wants to be displayed on the internet, and Eka Lesmana, Timon Adiyoso, and Soim Ramadhan as Google AdSense ad publishers also benefit from getting a commission from Google AdSense for clicks on AdSense ads that appear on websites owned by Eka Lesmana, Timon Adiyoso, and Soim Ramadhan.

From this description, it can be concluded that Google acts as an agent that uses the services of Eka Lesmana, Timon Adiyoso, and Soim Ramadhan as professional bloggers to display AdSense ads on their sites in the hope of being clicked by many website visitors. So it can be said that Eka lesmana et al's activities as a publisher of Google AdSense ads are activities related to free work.

It should be underlined that Eka Lesmana, Timon Adiyoso, and Soim Ramadhan were not paid by Google for creating content for Google, but they were paid for displaying adsnse ads and presenting website visitors who wanted to click AdSense ads. installed on the websites of theirs. they are paid with a pay per click system, meaning that the amount of income earned depends on the number of visitors who click on AdSense ads on the website of the three of them.

In addition, the activities of Eka Lesmana, Timon Adiyoso and Soim Ramadhan as Google AdSense Publishers are included in the type of e-commerce classified ads business, because they provide a place on his site to display Google-provided ads. text, graphics, explanatory videos, information, etc.) intended for users of the advertisement site visitors belonging to Eka Lesmana, Timon Adiyoso and Soim Ramadhan. Article 9 paragraph (1) Regulation of the Minister of Finance of the Republic of Indonesia number 210/PMK.010/2018 concerning the Tax Treatment of Trade Transactions through the Electronic System (E-Commerce) states that:

"The imposition of Value Added Tax, Sales Tax on Luxury Goods, and Income Tax on trade in goods and services through electronic systems (e-commerce) in the form of online retail, classified ads, daily deals, or social media, is carried out in accordance with statutory provisions in the field of taxation." [28]

So that Eka Lesmana, Timon Adiyoso and Soim Ramadhan as organizers of classified ads with status as PPh 23 tax subject will still be subject to PPh 23. However, specifically for Timon Adiyoso, aside from being a free worker subject to PPh 23, he can also be categorized as an employee. This is because Timon Adiyoso works as HRD and Supervisor at PT Surya Teknik Anugrah Site. So besides being subject to Article 23 Income Tax, Timon Adiyoso can also be subject to Article 21 Income Tax.

\section{(c) Tax obligations of Google AdSense ad publisher taxation}

Google AdSense ad publishers are subject to income tax, which can be a taxpayer if they meet subjective and objective requirements according to the provisions of Law Number 36 of 2008 regarding Income Tax. Transferring the position of the tax subject to a taxpayer, tax administration obligations will arise according to the provisions of Law Number 36 of 2008 concerning Income Taxes.. According to that law, tax administration obligations can be categorized based on the classification of work or source of income obtained by the taxpayer concerned [29].

From the subject that the writer examined, the work of Eka Lesmana, Soim Ramadhan, and Timon Adiyoso can be categorized into two types of work. Eka Lesmana and Soim 
Ramadhan as free workers, and Timon Adiyoso as employees as well as free workers. Then each uses the principle of meeting different tax obligations. Eka Lesmana, Soim Ramadhan and Timon Adiyoso as free workers use the principle of holding system. Especially for Timon Adiyoso who also works as an employee using the principle of holding system. Thus, the tax administration obligations as free workers of the three taxpayers can be illustrated as follows:

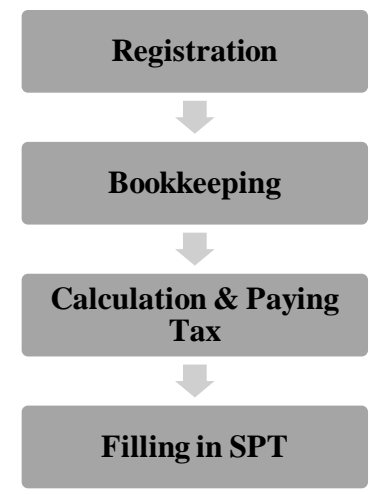

Figure 2. Tax administration obligations as free workers of the three taxpayers.

\subsection{Tax Administration Obligations of Google AdSense Ad Publishers as Article 23 Taxpayer Taxpayers}

\subsubsection{Obligation to Register Yourself}

Based on Article 2 paragraph (1) of Law Number 6 of 1983 (UU KUP) as amended several times, the latest by Law Number 16 of 2009 (UU KUP), taxpayers who have met the subjective and objective requirements in accordance with regulatory provisions Tax legislation must carry out achievements in the form of tax obligations, that is, register at the office of the Directorate General of Tax whose working area includes the residence or domicile of the Taxpayer. Taxpayers register with the Tax Service Office to obtain a Taxpayer Identification Number (NPWP) [30].

Based on interviews conducted by the author, Soim Ramadhan claimed to have NPWP. Soim Ramadan knows that he has to pay income tax on the income he earns as a Google AdSense ad publisher. Soim Ramadhan also believes that the AdSense income he earns will not be known and collected by tax officials as long as he does not share his AdSense income with others or show off on social media, meanwhile Soim Ramadan does not agree if jobs such as Google AdSense ad publishers, or the like are subject to income tax because it is very small when subjected to income tax, and will only reduce the amount of income earned[27].

While from interviews with Timon Adiyoso, the fact is that Timon Adiyoso already has a TIN. Timon Adiyoso claimed to have a tax ID for tax administration purposes from his main job as HRD and Supervisor at PT Surya Teknik Anugrah Site. Timon Adiyoso also knows that he must pay income tax on the income he earns as a Google AdSense ad publisher. He also agreed if Google AdSense ad publishers were subject to income tax. However, Timon Adiyoso chose not to answer when the author asked whether he had made payment and SPT reporting related to earnings from Google AdSense [25].

In contrast to Eka Lesmana, based on interviews conducted by the author, Eka Lesmana claimed not to have a NPWP. In addition, he also considers the matter of AdSense income tax 
already taken care of by Google, Google AdSense ad publishers such as Eka Lesmana only receive only net income. Eka Lesmana also knew that she had to pay income tax on the income she earned as a Google AdSense ad publisher, but she intended not to pay taxes because she thought that tax money would later be corrupted. Eka Lesmana chose to donate part of her AdSense income to orphans and people in need [26].

Based on the description above, it can be concluded that Eka Lesmana, Timon Adiyoso, and Soim Ramadhan are less aware and less concerned about the importance of the role of taxes. Besides that, there is a tendency not to be willing to pay taxes when obtaining income often leads to tax avoidance because in general a person tends to dislike and be reluctant to pay taxes, because it will reduce his income, and consider the results of taxation for the benefit of the authorities to see from the nature of the tax that does not receive compensation in return live [31].

Provisions in Article 39 paragraph (1) of Law Number 16 of 2009 (UU KUP) which states that a taxpayer can be subject to a maximum of 4 (four) times the amount of tax payable which is not or underpaid, if intentionally not registering and therefore it can cause harm to the country.

\subsubsection{Obligation to Keep Bookkeeping/Recording}

The second obligation of taxpayers is to keep records or records. Definition of accounting according to the KUP Law Article 1 paragraph (29) is a process of recording carried out regularly to collect financial data and information which includes assets, liabilities, capital, income and costs, as well as the total price of acquisition and delivery of goods or services, which closed by preparing a financial statement in the form of a balance sheet, and an income statement for the tax year [24].

In general, Article 28 paragraph (2) of Law Number 16 of 2009 (KUP Law) states that taxpayers who are obliged to hold records are individual taxpayers who carry out business activities or free work in accordance with the provisions of taxation laws allowed to calculate net income by using the Net Income and Taxpayers Norm Calculation of an individual who does not do business or free work. Recording is different from bookkeeping, KUP Law Article 28 paragraph (9) explains the recording consists of data collected regularly about gross circulation or revenue and/or gross income as a basis for calculating the amount of tax owed.

\subsubsection{The obligation to calculate and pay taxes owed in a timely manner}

The next taxpayer's obligation is to calculate and pay tax owed in a timely manner. This obligation has to do with the tax collection system, one of the tax collection systems implemented in Indonesia is the holding system applied to Income Tax Article 4 paragraph (2), Income Tax Article 21, Income Tax Article 22, Income Tax Article 23, Income Tax Article 24, and Income Tax Article 26. As a taxpayer of Income Tax Article 23, income tax collection for Eka Lesmana, Soim Ramadhan and Timon Adiyoso as free workers is carried out with a holding system, so Eka Lesmana, Soim Ramadhan and Timon Adiyoso are not required to play an active role in calculating taxes and depositing tax on income earned. The active role was taken over by tax cutters and employers who paid salaries to Eka Lesmana, Soim Ramadhan and Timon Adiyoso namely Google Asia Pacific Pte Ltd.

Google Asia Pacific Pte Ltd as the employer and who pays salary to Eka Lesmana, Soim Ramadhan and Timon Adiyoso can be categorized as a permanent establishment because it meets the criteria in Article 4 of the Minister of Finance Regulation No umber 35/PMK.03/2019 concerning Determination of Business Forms Permanent [32]. In general, 
the Article stipulates that a permanent establishment is a form of business used by foreign individuals or foreign entities that have a place of business to conduct business in Indonesia.

In fact, Google Asia Pacific Pte Ltd is a foreign entity domiciled in Singapore that has been carrying out business activities in Indonesia since 2012 through PT Google Indonesia having its address at Sentral Senayan II, Jalan Asia Afrika, Jakarta. Therefore, it clearly shows that Google Asia Pacific Pte Ltd has business activities in Indonesia and can be categorized as a permanent establishment and has an obligation to withhold taxes on the income of Eka Lesmana, Soim Ramadhan and Timon Adiyoso as Google AdSense ad publishers.

Eka Lesmana, Soim Ramadhan and Timon Adiyoso as recipients of net income after the deduction can collect evidence of deductions provided by the cutter namely Google Asia Pacific Pte Ltd. The cut evidence function can be used by Eka Lesmana and Soim Ramadhan as Article $23 \mathrm{PPh}$ taxpayers as proof that the person concerned has carried out tax obligations with deduction by the cutter and when reporting the Annual Tax Return.

\subsubsection{Obligation to Fill in and Submit SPT}

The fourth obligation for taxpayers is to fill out and submit a Tax Return (SPT), the obligation to fill out and submit a Tax Return (SPT) is regulated in Article 4 paragraph (1) of the KUP Law.

Based on Article 3 paragraph (1) of the KUP Law, Eka Lesmana, Soim Ramadhan and Timon Adiyoso as taxpayers are required to be active in filling SPT blanks correctly, clearly, and completely. Complete, which means all information and data requested has been filled as requested in the column provided and attaching required data and information.

If the taxpayer intentionally does not fill the tax return whose contents are incorrect or incomplete so that it can cause state losses, the taxpayer concerned will be subject to imprisonment for a minimum of 6 (six) months and a maximum of 6 (six) years and a fine of at least 2 (two) times the amount of tax payable that is not or not fully paid and at most 4 (four) times the amount of tax payable that is not or not fully paid.

Article 38 of the KUP Law also regulates sanctions for taxpayers for their negligence not submitting tax returns or submitted tax returns, but the contents are incorrect or incomplete, or attach information that is not true, the taxpayers must be fined at least 1 (one) times the amount of tax payable that is not or not fully paid and at most 2 (two) times the amount of tax payable that is not or less paid, or being imprisoned for a minimum of 3 (three) months or a maximum of 1 (one) year.

In accordance with Article 10 paragraph (1) letter g PMK SPT. Eka Lesmana, Soim Ramadhan and Timon Adiyoso have a deadline for reporting tax returns no later than 20 (twenty) days after the tax period ends. The Income Tax Return period Article 25 which is not submitted within the time limit, then Article 7 paragraph (1) KUP provides administrative sanctions to the taxpayer concerned in the form of a fine of Rp 1,000,000.00 (One Million Rupiah).

\subsubsection{Tax Administration Obligations of Taxpayer Article 21}

As working as an HRD and Supervisor at PT Surya Teknik Anugrah, Timon Adiyoso has been categorized as an employee so that his income as an employee may be subject to Article 21 Income Tax. Timon Adiyoso has worked as HRD and Supervisor at PT Surya Teknik Anugrah Site since 2013 and received a salary of Rp.121 million per year [26]. Judging from the amount of one year income obtained by Timon Adiyoso has exceeded PTKP so according to Law Number 36 of 2008 concerning Income Taxes, the income earned by Timon Adiyoso as HRD at PT Surya Teknik Anugrah Site can be subject to Income Tax article 21. 
According to Law number 16 of 2009 (UU KUP) Tax administration obligations that Timon Adiyoso has to do first are to register themselves to obtain a TIN. NPWP is useful as an identification of taxpayers in carrying out taxation rights and obligations as well as to maintain order in tax payments and in the supervision of tax administration [33]. From the results of the author's interview, Timon Adiyoso explained that he already has a TIN [26].

The second Timon Adiyoso tax administration obligation is to report the tax return. the obligation to fill out and submit a Tax Return (SPT) is regulated in Article 4 paragraph (1) of the KUP Law. The SPT serves as a means to account for the fulfillment of tax obligations within a tax period or tax year. From the results of the author's interview, Timon Adiyoso explained that he had reported the SPT [34].

Both obligations must be carried out by Timon Adiyoso as the PPh 21 taxpayer, while the obligation to collect, calculate and deposit PPh 21 has been carried out by the revenue provider, PT Surya Teknik Anugrah Site. PT Surya Teknik Anugrah Site as the income giver must also issue proof of withholding Article 21 Income Tax to Timon Adiyoso as the party whose income is collected with Article 21 Income. The withholding evidence will later be attached to Timon Adiyoso at the time of Annual SPT reporting as proof that the person concerned has carried out tax obligations with cut by the cutter [34].

\subsection{Earnings as a publisher of Google AdSense ads as an income tax object}

Law Number 36 of 2008 concerning Income Taxes adheres to the principle of taxation of income in the broadest sense, namely that taxes are imposed on any additional economic capability that is received or obtained by the Taxpayer from whatever origin it can be used for consumption or to add to the wealth of the Taxpayer [35]. Earnings Eka Lesmana and Soim Ramadhan as Google AdSense ad publishers are subjected to income tax objects because Eka Lesmana and Soim Ramadhan use their income as Google AdSense ad publishers for consumption and adding wealth.

As explained earlier, the income of Eka Lesmana, Timon Adiyoso, and Soim Ramadhan from displaying AdSense ads on the website of the three of them was identified as a reward in connection with the provision of place and/or time in mass media, outdoor media or other media for the delivery of information, and/or advertising services as stipulated in the Regulation of the Minister of Finance of the Republic of Indonesia Number 141/PMK.03/2015 concerning Other Types of Services as referred to in Article 23 Paragraph (1) Letter C Number 2 of Law Number 36 of 2008 concerning Income Tax [36]. So based on these conditions, Eka Lesmana, Timon Adiyoso and Soim Ramadhan's income as Google AdSense ad publishers are subject to an income tax of $2 \%$ of the gross amount by the slicer, Google Asia Pacific as the income provider.

According to article 23 paragraph (1) of Law Number 36 of 2008 regarding Income Taxes, Google Asia Pacific Pte Ltd as a party with status as a permanent income provider is required to deduct taxes on AdSense income obtained by Eka Lesmana, Timon Adiyoso, and Soim Ramadhan . However, the results of interviews with the three speakers obtained the fact that the AdSense earnings that Eka Lesmana, Timon Adiyoso, and Soim Ramadhan as Google AdSense ad publishers have not been deducted by Google Asia Pacific Pte Ltd's income tax. This is known from the absence of proof of deductions or proof of tax payments attached to the Google AdSense payment dashboard or on the invoice when withdrawing the income in Western Union or at the Bank, one feature in an AdSense account that displays payments received by Google AdSense Ad Publishers in one month. 
Based on the information obtained by the author through an interview with Jeanny Haliman as a representative of the Google Asia Pacific Pte Ltd in the Google For Publishers Semarang event explained that Google does not cut income tax on its ad publishers. Jeanny added, Google Asia Pacific Pte Ltd as a company that houses Google AdSense ad publishers in the Asian region has difficulty implementing tax collection on the AdSense revenue earned by advertisers in the Asian region because the tax regulations of each country in Asia are different and often keep changing. Thus, it would be wise to hand over the income tax affairs of Google AdSense ad publishers to each ad publisher in accordance with the tax regulations of the place where the advertisers in question live [37].

According to the provisions in article 13 paragraph (3) letter b of Law Number 28 of 2007 concerning General Provisions and Tax Procedures (KUP), if the results of the inspection by the DGT to Google Asia Pacific Pte Ltd are found to have not carried out tax collection, deposit and reporting on the income of Google AdSense ad publishers resulting in the tax payable not being paid, the DGT will issue an Underpayment Tax Assessment Letter and impose administrative sanctions in the form of a proportional increase in the amount of tax that must be added to the underpaid tax amount of $100 \%$ [38].

\section{Conclusion}

The Google AdSense publisher, including the subject of income tax, is subjected to income tax because the Google AdSense publisher is a domestic personal tax subject who earns income from Google Asia Pacific Pte. Ltd.

The Google AdSense publisher is also categorized as rewards relating to services used as additional economic capabilities or increase wealth and be consumed by Google AdSense ad publishers (publishers).

The income of the Google AdSense advertiser (publisher) is identified as a reward in connection with services providing a place and/or time in the mass media, outdoor media or other media for the delivery of information, and/or advertising services as governed by Regulation of the Minister of Finance of the Republic of Indonesia Number 141/PMK.03/2015 concerning Other Types of Services as referred to in Article 23 Paragraph (1) Letter C Number 2 of Law Number 36 of 2008 concerning Income Taxes so that Google AdSense advertiser (publisher) income is subject to Article 23 Income Tax.

Tax obligations of individual taxpayers who work as Google AdSense publishers refer to the provisions of Law Number 16 of 2009 (UU KUP), regulating the administrative obligations of Google AdSense publisher advertisers, specifically written on Article 2 paragraph ( 1) Law Number 16 of 2009 (KUP Law) which states that Google AdSense advertisers have the obligation to register themselves to obtain a Taxpayer Identification Number (NPWP), the next obligation is to hold records (Article 28 paragraph (1) and (2) Law Number 16 of 2009 (KUP Law), hereinafter Article 4 paragraph (1) of Law Number 16 of 2009 (KUP Law) also mentions the obligation of a Google AdSense ad publisher to fill out and submit Annual Tax Returns , and for the cutter, Google Asia Pacific Pte. Ltd is required to deduct, calculate the filling and submit a periodic tax return for withholding tax.

However, the fact is that Google Asia Pacific Pte. Ltd. as a cutting party with the status of BUT according to the Minister of Finance Regulation No. 35/PMK.03/2019 concerning Determination of Permanent Establishment does not cut the income of Google AdSense advertisers because it has difficulty adjusting tax regulations in each country and hand over 
Google AdSense income tax affairs to each ad publisher in accordance with the tax regulations of the place where the advertisers in question live. So that the Google AdSense advertiser (publisher) does the calculation, deposit/payment of income tax Article 23, and reporting tax returns independently.

The suggestions that can be submitted in this article are to remind Google Asia Pacific Ltd as a taxpayer of Permanent Establishment (BUT) to cut income and publish proof of deduction to Google AdSense advertisers in Indonesia so that publishers of Google advertisers AdSense in Indonesia makes it easy to carry out its tax obligations.

The Directorate General of Taxes through the local tax office can disseminate to Google AdSense advertisers about tax obligations and tax law enforcement to Google AdSense advertisers who do not implement and comply with their tax obligations. They also needs to promote strict sanctions such as administrative sanctions and criminal sanctions that have been regulated in Law Number 36 of 2008 (PPh Law) and Law Number 16 of 2009 (KUP Law) to Google AdSense ad publishers who do not implement and comply with tax obligations. 


\section{References}

[1] A. . Darma, J. S., and Shenia, Buku Pintar Menguasai Internet. Jakarta: MediaKita, 2009.

[2] D. Michael, B., Theaker, A., and Wragg, Hubungan Media Yang Efektif. Jakarta: Erlangga, 2004.

[3] Y. A. Zein, Kontrak elektronik \& penyelesaian sengketa bisnis e-commerce dalam transaksi nasional \& internasional. Bandung: Mandar Maju, 2009.

[4] S. Susiana, "Pelindungan Hak Pekerja Perempuan dalam Perspektif Feminisme," J. Aspir., vol. 8, no. 2, pp. 207-221, 2019.

[5] Y. I. Diva, J., and Winanta, "Metode Untuk Memajukan Usaha Bisnis Online di Kalangan Anak Muda Universitas Widya Mandala," in The 7th NCFB and Doctoral Colloquium 2014 Towards a New Indonesia Business Architecture Sub-Theme: "Business and Economic Transformation towards AEC 2015”,.

[6] Tribun Jateng, "Eka Kini Jutawan Setelah Berhenti Angon Bebek lalu Bergabung Google AdSense," 23 Feb 2015. [Online]. Available: https://jateng.tribunnews.com/2015/02/23/eka-kini-jutawan-setelah-berhenti-angonbebek-lalu-bergabung-google-adsense.

[7] Kompas.com, "Dulu Angon Bebek, Kini Beternak Blog." [Online]. Available: https://regional.kompas.com/read/2016/03/04/07000071/Dulu.Angon.Bebek.Kini.Bete rnak.Blog.

[8] Asosiasi Penyelenggara Jasa Internet Indonesia (APJII), "Hasil Survei Penetrasi dan Perilaku Pengguna Internet Indonesia 2017." [Online]. Available: https://www.apjii.or.id/content/read/39/342/Hasil-Survei-Penetrasi-dan-PerilakuPengguna-Internet-Indonesia-2017.

[9] M. B. Steger, Globalization: A very short introduction. Vol. 86. Oxford: Oxford University Press, 2017.

[10] Supriyanta, Interaksi Manusia \& Komputer. Yogyakarta: Deepublish, 2019.

[11] P. D., Komunikasi Bisnis. 3 ed. Jakarta: Erlangga, 2011.

[12] Y. Supardi, Internet untuk Segala Kebutuhan. Jakarta: Elex Media Komputindo, 2009.

[13] S. Prawira, Membongkar fenomena bisnis internet. Jakarta: Elex Media Komputindo, 2010.

[14] N. W. Sakti, Buku Pintar Pajak E-Commerce. Jakarta: Visimedia, 2014.

[15] O. Yusuf, "Pengguna Internet Indonesia Nomor Enam Dunia. (24 Nov 2014)." [Online].

Available: https://tekno.kompas.com/read/2014/11/24/07430087/Pengguna.Internet.Indonesia.No mor.Enam.Dunia. [Accessed: 28-Aug-2019].

[16] A. Hartoko, Menjadi Kaya dan Terkenal dengan Blogspot. Jakarta: Elex Media Komputindo, 2010.

[17] J. Helianthusonfri, Passive Income dari Google AdSense. Jakarta: Elex Media 
Komputindo, 2018.

[18] and S. C. Alamsyah, F., Meraih Penghasilan dengan Google AdSense. Jakarta: Elex Media Komputindo, 2013.

[19] N. Sa'adah, "Kebijakan Tax Amnesty dan Fungsinya Bagi Negara,” Adm. Law Gov. J., vol. 1, no. 1, pp. 44-47, 2018.

[20] A. Sutedi, Hukum Pajak. Jakarta: Sinar Grafika, 2011.

[21] Law Number 36 of 2008 concerning Income Taxes. .

[22] Y. R. Basuki, Mengenal Perpajakan: AZ Perpajakan. Jakarta: Magic Entertainment, 2017.

[23] W. D. Ernawati, Perpajakan Terapan Lanjutan. Malang: Polinema Press, 2018.

[24] D. Muljono, Panduan Brevet Pajak: Pajak Penghasilan. Yogyakarta: Penerbit Andi, 2015.

[25] Interview with Eka Lesmana, Google AdSense Indonesia publisher who lives in Karanganyar on May 4, 2019, at 8:00 AM. .

[26] Interview with Timon Adiyoso, a Google AdSense Indonesia publisher living in Samarinda on May 3 2019, at 17:45 PM. .

[27] Interview with Soim Ramadhan, Google AdSense Indonesia publisher who lives in Kartasura on 5 March 2019, at 13:00 PM. .

[28] Regulation of the Minister of Finance of the Republic of Indonesia number 210/PMK. 010/2018 concerning the Tax Treatment of Trade Transactions through the Electronic System (E-Commerce). .

[29] C. A. Pohan, Manajemen Perpajakan strategi perencanaan pajak dan bisnis. Jakarta: Gramedia Pustaka Utama, 2013.

[30] F. S. Adiyanta, "Kebijakan Penghapusan Sanksi Administrasi Perpajakan sebagai Stimulus Peningkatan Penerimaan Negara dari Sektor Pajak (Studi Evaluatif Normatif Kebijakan Perpajakan Nasional)," Adm. Law Gov. J., vol. 1, no. 2, pp. 165-181, 2018.

[31] F. S. Adiyanta, Penyanderaan Wajib Pajak. Semarang: Adiswara, 2008.

[32] Regulation of the Minister of Finance Number 35/PMK.03/2019 concerning Determination of Permanent Establishment. .

[33] Interview with Surakarta Pratama Tax Office Public Relations on June 10, 2019, at 09:00. .

[34] "Interview with Surakarta Pratama Tax Office Public Relations on June 10, 2019, at 09:00."

[35] B. A. A., Panduan Lengkap Pajak Penghasilan. Jakarta: Transmedia Pustaka, 2011.

[36] Regulation of the Minister of Finance of the Republic of Indonesia Number 141/Pmk.03/2015 concerning Other Types of Services as referred to in Article 23 Paragraph (1) Letter C Number 2 of Law Number 36 of 2008 concerning Income Taxes. . 
[37] Interview with Jeanny Haliman (South East Asia Web Lead of Google's Online Partnership Group) on July 17, 2019, at 09:00 AM. .

[38] "Law Number 28 of 2007 concerning General Provisions and Tax Procedures." 